\title{
Antimicrobial and cytotoxic activities of Tripleurospermum parviflorum (Willd.) Pobed
}

\author{
Tuğçe Fafal Erdoğan1, Tuba Mert Gönenç 1, Mustafa Oskay²
}

\begin{abstract}
The antimicrobial and cytotoxic activities of $\mathbf{n}$-hexane, methanol, ethanol, ethyl acetate and water extracts of Tripleurospermum parviflorum (Willd.) Pobed. were evaluated in this study. The antimicrobial activities of the extracts were reported against Escherichia coli ATCC 29998, Escherichia coli ATCC 25922, Escherichia coli ATCC 11230, Staphylococcus aureus ATCC 6538P, Staphylococcus aureus ATCC 29213, Enterobacter cloacae ATCC 13047, Enterococcus faecalis ATCC 29212, Pseudomonas aeroginosa ATCC 27853 as bacteria and Candida albicans ATCC 10239 as yeastlike fungi by disc diffusion method. Cytotoxic activity of the extracts was tested in vitro against Brine shrimp. All of the extracts showed a range of activity against the tested bacteria and brine shrimp.
\end{abstract}

KEY WORDS: Tripleurospermum parviflorum, Asteraceae, cytotoxic activity, antimicrobial activity.

\section{INTRODUCTION}

The genus Tripleurospermum Sch. Bip. belongs to the tribe Anthemideae of the family Asteraceae (Compositae) and is composed of about 38 species distributed mainly in Europe and temperate Asia, with a few species also in North Africa (1). The genus is represented by 26 taxa at the level of species and variety in the flora of Turkey (2). Most of these are distributed in the North and East Anatolia. Tripleurospermum species known locally papatya are extensively used in Turkey as a foodstuff. The decoction and infusion prepared from T. parviflorum (Willd.) Pobed. and T. monticolum (Boiss. \& Huet) Bornm are used against cough and stomachache and as antipyretic. T. parviflorum was also reported to have usage against throat diseases and vaginitis (3). T. sevanense (Manden.) Pobed. is used externally for hair care in Turkey (4). Some of the species of Tripleurospermum have been used in Iranian herbal medicine for soothing, calming, relaxation, as sedative and against tenseness, exhaustion and stress (5). The flowers have also been used as a carminative, stimulant and febrifuge (6).
Tripleurospermum species contain a variety of chemical compounds such as terpenes, hydrocarbons, steroids, oxygenated compounds, flavonoids, alcohols, acids and aromatic compounds (8) and have wide range of biological activities such as antioxidant (9), anti-inflammatory, analgesic $(5,10)$ and antifungal (11). Nevertheless, no report about the cytotoxicity of this plant is found in the literature. In previous study, a compilation of literature data on the antimicrobial activity of T. disciforme (C.A. Mey) Schultz Bip. methanol extract has been given (11).

In this study the possible inhibitory activity of $T$. parviflorum extracts against various microorganisms and the cytotoxicity against Brine shrimp were evaluated (7).

\section{MATERIALS AND METHODS \\ Plant Material}

T. parviflorum was collected from İzmir-Bozdağ in May 2007. They were identified by Prof. Dr. Bijen Kıvçak from Ege University, İzmir, Turkey. The voucher specimen (herbarium number: 1366) is deposited in the herbarium of the Faculty of Pharmacy, Ege University, İzmir, Turkey.
AFFILIATIONS

1Ege Üniversitesi Eczacılık Fakültesi, Farmakognozi Anabilim Dalı, İzmir, Türkiye ${ }^{2}$ Celal Bayar Üniversitesi Fen Edebiyat Fakültesi, Biyoloji Bölümü Mikrobiyoloji Anabilim Dalı, Manisa, Türkiye

\section{CORRESPONDENCE} Tuğçe Fafal Erdoğan

E-mail: tugce.fafal@ege.edu.tr

Received:

31.07.2012

Revision:

28.08.2012

Accepted:

23.09.2012 


\section{Preparation of Plant Extracts}

Air dried and powdered leaves of T. parviflorum (20 g) were extracted with $n$-hexane, ethanol, methanol, ethyl acetate and water (infusion) (1:10) at room temperature; the extracts were evaporated to dryness in vacuo and weighed.

\section{Cytotoxic Studies}

Cytotoxicity was studied by Brine shrimp (Artemia salina) assay (12). Cytotoxic activity of all extracts were compared with umbelliferone and colchicine as the active cytotoxic substances $(13,14)$.

\section{Materials}

Brine shrimp was obtained from San Fransico Bay Brand Inc. Newark, CA94560 USA. Sea salt (Sigma-9883) were used in activity tests. The small tank was purchased from Otsuka Pharmaceutical Co. Ltd., (Tokyo, Japan).

\section{Method}

Cytotoxicity was evaluated by the brine shrimp lethality bioassay (12). The sea salt (3.8 g) was dissolved in $100 \mathrm{ml}$ water and filtrated. Brine shrimp (Artemia salina) eggs were placed into the sea water and allowed to incubate for $48 \mathrm{~h}$ at $28^{\circ} \mathrm{C}$ in a small tank. Each extracts were tested at 1000, 100 and 10 ppm. $20 \mathrm{mg}$ plant extract was dissolved in $2 \mathrm{ml}$ of chloroform to prepare a stock solution of $10 \mathrm{mg} / \mathrm{ml}$. From the stock solution, 500, 50 and $5 \mu \mathrm{l}$ was transferred to different vials and allowed to evaporate. After evaporation, $5 \mathrm{ml}$ of sea salt solution was added to each vial to prepare concentrations corresponding to 1000, 100 and 10 ppm. Each concentration was prepared in triplicate. Also, a vial including chloroform $(500 \mathrm{ml})$ was prepared for control. After incubation, 10 brine shrimp larvae (nauplii) were introduced into vials containing graded concentrations (ranging from 10 to $1000 \mathrm{ppm}$ ) of the test extracts. After $24 \mathrm{~h}$, the number of surviving shrimps at each concentration of the extracts was counted and data was analyzed with Finney Computer program to determine the $\mathrm{LC}_{50}$ at $95 \%$ confidence interval.

\section{Antimicrobial Studies}

The disc diffusion method, known as the Kirby Bauer method, was used the determine antimicrobial activities (15-17).

$24 \mathrm{~h}$ cultures containing $10^{8} \mathrm{cfu} / \mathrm{ml}$ of microorganisms were used and diluted with sterile distilled water to obtain equivalent to $0.5 \mathrm{Mc}$ Farland's standards of turbidity. $24 \mathrm{~h}$ cultures of the yeast were prepared in Saboraud Dextrose Broth to obtain $10^{7} \mathrm{cfu} / \mathrm{ml} .40 \mu \mathrm{l}$ of reconstituted crude extracts were absorbed on to the sterile $6 \mathrm{~mm}$ discs (Oxoid Antibacterial Suspectibility Blank Tests Disc) under aseptic conditions to obtain $30 \mu \mathrm{g}$ extract/disc and dried at $50^{\circ} \mathrm{C}$. Dried discs were transferred on to the plates containing test organisms with sterile forceps. Control disc contained $40 \mu \mathrm{l}$ of sterile $10 \%$ aqueous DMSO. Agar plates containing bacteria were incubated at $37^{\circ} \mathrm{C}$ for 24 $\mathrm{h}$ and those containing yeast at $27{ }^{\circ} \mathrm{C}$ for $48 \mathrm{~h}$. The standard antibacterial agent Ceftazidime $(30 \mu \mathrm{g} /$ disc $)$ was used as a positive control for bacteria and the standard antifungal agent Nystatin $(25 \mu \mathrm{g} /$ disc) was used as the positive control for yeast. All experiments were done in triplicate.

\section{Test Microorganisms}

The following Gram (+) and Gram (-) bacteria were used for testing antibacterial activity: Escherichia coli ATCC 29998, Escherichia coli ATCC 25922, Escherichia coli ATCC11230, Staphylococus aureus ATCC 6538P, Staphylococcus aureus ATCC 29213, Enterobacter cloacae ATCC 13047, Enterococcus faecalis ATCC
29212, Pseudomonas aeriginosa ATCC 27853 were used as bacteria and Candida albicans ATCC 10239 as yeastlike fungi.

Lyophilised bacteria and yeast were Standard ATCC microorganisms obtained from the culture collection of the Science Faculty of Celal Bayar University, Section of Basic and Industrial Microbiology.

\section{Media}

The solid growth medium used for bacteria was Mueller Hinton Agar (Oxoid) and for yeastlike fungi was Saboraud Dextrose Agar (Difco).

\section{RESULTS AND DISCUSSION}

Cytotoxic activity of $n$-hexane, ethanol, methanol, ethyl acetate and water extracts of T. parviflorum have been investigated in vivo against Brine shrimp (Artemia salina). The results were reported in Table 1.

All of the extracts showed cytotoxic activity against Brine shrimp $\left(\mathrm{LC}_{50}<1000\right)$. Methanol extract has exhibited more cytotoxic activity than the other tested extracts. All extracts except water extract were even more active than a cytotoxic substance umbelliferon (13), but they were less active than colchicine (14).

TABLE 1. Cytotoxicity assay of $T$. parviflorum extracts against Artemia salina

\begin{tabular}{lccc}
\hline Extracts & $\begin{array}{c}\text { Concentration } \\
(\mathbf{p p m})\end{array}$ & $\begin{array}{c}\mathbf{L C}_{\mathbf{5 0}} \\
(\boldsymbol{\mu} \mathbf{g} / \mathbf{m l})\end{array}$ & $\begin{array}{c}\text { Extraction } \\
\text { Yield\% }\end{array}$ \\
\cline { 2 - 4 } Methanol & $1000: 100: 10$ & 57.0045 & 6.52 \\
n-Hexane & $1000: 100: 10$ & 92.6750 & 0.83 \\
Ethanol & $1000: 100: 10$ & 68.0005 & 4.13 \\
Ethyl acetate & $1000: 100: 10$ & 82.3589 & 1.41 \\
Water & $1000: 100: 10$ & 857.7312 & 4.52 \\
Colchicine (Standard) & $500: 50: 5$ & 0.0009 & \\
Umbelliferone (Standard) & $500: 50: 5$ & 377.0223 &
\end{tabular}

Results from the antimicrobial screening tests were shown in Table 2. As clearly seen in Table 2, the growth of Staphylococcus aureus ATCC 6538P was more inhibited by the whole extracts than Ceftazidime.

TABLE 2. Antimicrobial activity of $T$. parviflorum extracts

\begin{tabular}{|c|c|c|c|c|c|c|c|c|}
\hline \multirow[b]{2}{*}{ Microorganisms } & \multirow[b]{2}{*}{$A$} & \multicolumn{5}{|c|}{ Inhibition Zone (mm)* } & \multirow[b]{2}{*}{$G$} & \multirow[b]{2}{*}{$\mathrm{H}$} \\
\hline & & $B$ & C & $\mathrm{D}$ & $E$ & $\mathrm{~F}$ & & \\
\hline Escherichia coli ATCC 29998 & 6 & 6 & 5 & 6 & 6 & 16 & - & - \\
\hline Escherichia coli ATCC 25922 & - & - & - & 12 & 10 & 14 & - & - \\
\hline $\begin{array}{l}\text { Escherichia coli } \\
\text { ATCC } 11230\end{array}$ & 8 & 8 & 8 & 9 & 8 & 18 & - & - \\
\hline $\begin{array}{l}\text { Staphylococus aureus } \\
\text { ATCC } 6538 P\end{array}$ & 16 & 10 & 18 & 16 & 0 & 12 & - & - \\
\hline $\begin{array}{l}\text { Staphylococcus aureus } \\
\text { ATCC } 29213\end{array}$ & 10 & 12 & 10 & 14 & 10 & 8 & - & - \\
\hline $\begin{array}{l}\text { Enterobacter cloacae } \\
\text { ATCC } 13047\end{array}$ & - & - & - & 8 & - & 12 & - & - \\
\hline $\begin{array}{l}\text { Enterococcus faecalis } \\
\text { ATCC } 29212\end{array}$ & - & - & - & 10 & - & 10 & - & - \\
\hline $\begin{array}{l}\text { Pseudomonas aeroginosa } \\
\text { ATCC } 27853\end{array}$ & 8 & 9 & 6 & 8 & 8 & 18 & - & - \\
\hline $\begin{array}{l}\text { Candida albicans } \\
\text { ATCC } 10239\end{array}$ & - & - & - & - & - & - & 18 & - \\
\hline
\end{tabular}


All of the extracts inhibited the growth of Escherichia coli ATCC 29998, Escherichia coli ATCC 11230, Staphylococus aureus ATCC 6538P and Staphylococcus aureus ATCC 29213. The growth of Enterobacter cloacae ATCC 13047 and Enterococcus faecalis ATCC 29212 were only inhibited by the methanol extracts. None of the tested extracts showed activity against Candida albicans.

However, the standard antibacterial agent, Ceftazidime, inhibited the growth of all of the tested microorganisms but had no effect on the growth of Candida albicans. On the other hand, the standard antifungal agent, nystatine, inhibited the growth of Candida albicans but had no effect on the growth of bacteria. DMSO also did not effect the growth of any tested microorganisms.

In conclusion, all of the extracts showed a range of activity against the tested bacteria and brine shrimp. The antibacterial activity of the extracts against Staphylococcus aureus ATCC 29213 was more than Ceftazidime. On the other hand, the most significant cytotoxic activity was found in ethanol, methanol and eth$\mathrm{yl}$ acetate extracts. The present study indicates that the methanol, $n$-hexane, ethanol, ethyl acetate and water extracts of $T$. parviflorum have got profound cytotoxic and antimicrobial effect and may have potential use in medicine. From the previous studies it may be concluded that terpenes, hydrocarbons, steroids, oxygenated compounds, flavonoids, alcohols, acids and aromatic compounds are responsible for aforementioned activity (8). This novel finding will aid us to conduct bioactivity guided isolation and characterization of leading compounds in due course. These results provide a support to some of the uses of the plant in Turkish folk medicine. Further studies are, therefore, needed to confirm its efficacy and to evaluate its safety.

\section{Tripleurospermum parviflorum (Willd.) Pobed.'in antimikrobiyal ve sitotoksik aktiviteleri}

ÖZET: Bu çalışmada, Tripleurospermum parviflorum (Willd.) Pobed.'nin n-hegzan, metanol, etanol, etil asetat ve su ekstrelerinin, antimikrobiyal ve sitotoksik aktiviteleri değerlendirildi. Ekstrelerin antimikrobiyal aktiviteleri, bakteri olarak Escherichia coli ATCC 29998, Escherichia coli ATCC 25922, Escherichia coli ATCC 11230, Staphylococcus aureus ATCC6538P, Staphylococcus aureus ATCC 29213, Enterobacter cloacae ATCC 13047, Enterococcus faecalis ATCC 29212, Pseudomonas aeroginosa ATCC 27853 ve mantar olarak Candida albicans ATCC 10239'a karşı disk difüzyon metodu ile tayin edildi. Ekstrelerin sitotoksik aktiviteleri Brine shrimp yöntemiyle değerlendirildi. Ekstrelerin hepsi denenen bakterilere ve Brine shrimp'e karşı anlamlı aktivite gösterdi.

ANAHTAR SÖZCÜKLER: Tripleurospermum parviflorum, Asteraceae, sitotoksik aktivite, antimikrobiyal aktivite.

\section{REFERENCES}

1. Bremer K, Humphries C. Generic Monograph of the Asteraceae - Anthemideae. Bull Nat Hist Mus Bot 1993; 23: 71-177.

2. Yildirımlı S. The Chorology of the Turkish Species of Asteraceae Family. The Herb J Systemat Bot 1999; 6: 75-123.

3. Cakilcioglu U, Turkoglu I. An Ethnobotanical Survey of Medicinal Plants in Sivrice (Elazığ-Turkey). J Ethnopharmacol 2010; 132: 165-75.

4. Altundag E, Ozturk M. Ethnomedicinal Studies on the Plant Resources of East Anatolia, Turkey. Procedia - Social and Behavioral Sciences 2011; 19: 756-77.

5. Hosseini M, Parvini S, Bakhtiarian A. Anti-inflammatory, Analgesic Activity of Tripleurospermum disciforme Extracts in Rats. Toxicol Mech Method 2007; 17: 575-80.

6. Hooper D, Field H, Dahlgrey BE. Useful Plants and Drugs of Iran and Iraq. In: Field Museum of Natural History, Chicago. 1937, pp. 84-180.

7. Mc Laughlin JL, Chang CJ, Smith DL. Bench-Top Bioassays the Discovery of Bioactive Natural Products: an update. Nat Prod Chem 1991; 9: 383-97.

8. Yasar A, Ucüncü $O$, Gülec $C$, İncer $H$, Ayaz $S$, Yayla N. GC-Ms Analysis of Chloroform Extracts in Flowers, Stems and Roots of Tripleurospermum callosum. Pharm Biol 2005; 43: 108-12.

9. Wichtl M. Herbal Drugs and Phytopharmaceuticals. Medpharm, Scientific Publishers, Stuttgart. 2004.
10. Bakhtiarian A, Ejtemaimehr S, Strobl S, Tehrani S P, Partoazar A, Ghamami G, Yasa N. Inhibition of Carregeenan-induced Edema by Tripleurospermum disciforme Extracts in Rats. Pakistan J Biol Sci 2007; 10: 2237-40.

11. Amin G, Dehmoobed-Sharifabadi A, Salehi Surmaghi MS, Yasa N, Aynechi Y, Emami M, Shidfar M, Amin M, Moghadami M, Kordbacheh P, Zeini F. Screening of Iranian Plants for Antifungal Activity. Daru 2002; 10: 38-48.

12. McLaughlin JL, Chang CJ, Smith DL. Bench - top bioassay for the discovery of bioactive natural products. An update. In : Studies in natural product chemistry. Editor: Atta-ur-Rahman, Elsevier science publishers. Amsterdam. 1991. pp. 383-409.

13. Jimenez OFA, Molina GJA, Mendoza PN, Leon CF, Flores PB, Santos SE, Mandoki IJ. Cytostatic Activity of Coumarin Metabolites and Derivatives in the B-16-F-10 Murine Melanoma Cell Line. Mel Res 1999; 9: 243-7.

14. Lee KH. Novel Antitumor Agents from Higher Plants. Med Res Rev 1999; 19: 569-96.

15. Collins CM, Lyne PM, Microbiological Methods, Butterworths Co. Ltd., London. 1987.

16. NCCLS, Performance Standarts for Antimicrobial Disc Suspectibility Tests. Approved Standard NCCLS Publication $\mathrm{M}_{2}-\mathrm{A}_{5}$, Villanova, PA, USA. 1993.

17. Gür D. Antibiyotik Duyarlılık Testleri: Antibiyotiklere Direnç Mekanizmaları ve Antibiyotik Duyarlılık Testleri. Pfizer İlaçları A.Ş. Kitaplar Serisi, İstanbul. 1992. 